\title{
ENTRE O PAMPA E O MAR: QUESTÕES DE CIVILIZAÇÃO E BARBÁRIE
}

\author{
Lívia Petry Jahn* \\ Universidade Federal do Rio Grande do Sul
}

Resumo: Este ensaio tem por objetivo discutir questões abordadas na metaficção historiográfica contemporânea como a noção de herói problemático, a revisão das ideologias e

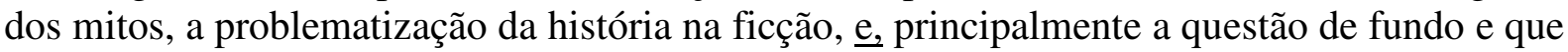
guia este trabalho: a noção de civilização e barbárie que perpassa a construção da identidade Ocidental. Para tanto, usamos a abordagem teórica de Bakhtin (1990), Benjamin (1985), Wolff apud Novaes (2004) e Rodrigues (2000). Assim, buscamos abordar tanto no romance "O Pintor de Retratos" de Assis Brasil (2001), quanto "As Naus" de Lobo Antunes (2011), os aspectos enumerados acima.

Palavras-chave: Metaficção Historiográfica Contemporânea. Ficção. Civilização. Barbárie. Herói Problemático.

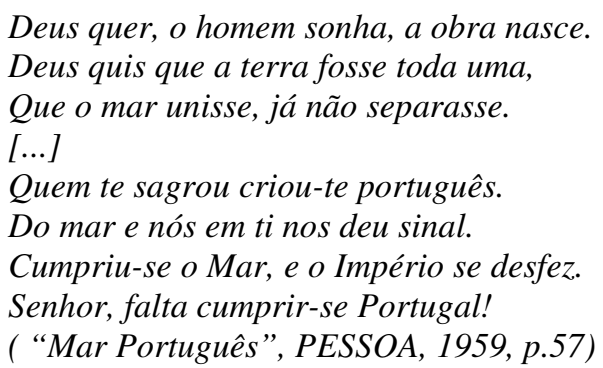

\section{Introdução}

Segundo Nancy Huston (2010), o que distingue a humanidade não é somente a capacidade de raciocinar e criar teorias (como a Teoria da Relatividade de Einstein) e prédios (como as grandes pirâmides do Egito), mas sim, a capacidade de narrar, de ser uma "espécie fabuladora". Tudo na vida humana constitui-se em narrativas, e a história das civilizações não é mais do que uma imensa, imemorial, junção de narrativas e gestos. A arte tanto da oratória

\section{$\Theta(\Theta \Theta \Theta$}

BY NC ND Esta obra está licenciada sob uma Licença Creative Commons.

\footnotetext{
* Doutoranda do Curso de Letras da Universidade Federal do Rio Grande do Sul. Mestre em Literatura Portuguesa e Luso-Africanas pela UFRGS com bolsa CAPES. Atualmente desenvolve pesquisa de Doutorado sobre o tema "Cantigas de Terno de Reis em Santa Catarina e nos Açores" e é Professora Colaboradora de Literatura Brasileira na Universidade Estadual do Centro-Oeste (Paraná).
} 
quanto da escrita, existiriam dessa maneira, para perpetuar as memórias e as tradições. $\mathrm{O}$ romance histórico contemporâneo é, nesse viés, uma forma de rememorar e recontar a história e o passado recente das várias civilizações. Mas não é só isso: é também uma forma de fazer uma releitura desse passado, ressignificando no presente, os heróis, os acontecimentos, os mitos de uma dada sociedade. Assim, este tipo de romance leva-nos imediatamente à reflexão e ao questionamento da "história oficial" apresentada nos livros escolares.

Ao contrário da epopeia, que traz em si um mundo fechado e cognoscível, o romance contemporâneo não traz respostas prontas, mas sim, questionamentos. $\mathrm{O}$ mundo do romance contemporâneo é, na realidade, um mundo em processo, inacabado, sem soluções imediatas, mas apenas questões a serem pensadas criticamente. Se na epopeia o herói representa a coletividade, no romance contemporâneo ele representa o indivíduo solitário, complexo, e, no mais das vezes, sem rumo certo. Assim, o herói do romance pode tanto seguir uma trajetória tradicional, delineada por Propp (1984), (que vai desde uma falta até a superação dos obstáculos e antagonistas chegando a um final feliz e de preenchimento da falta inicial), como pode também subvertê-la, saindo de uma falta inicial e acabando numa falta final, na fragmentação do sujeito, no paroxismo e na perplexidade, no auge da miséria e da perda de identidade. Por isso, o herói contemporâneo é um anti-herói, ou pelo menos, um herói sem saída, sem final feliz, sem uma realidade que o complete seja na esfera objetiva, seja na esfera subjetiva.

Neste âmbito, o romance histórico contemporâneo se constrói como antiepopeia: ele é o lugar por excelência do indivíduo problemático, e o entre-lugar da história. Entre-lugar da história porque na ficção a história, os personagens que a constituem, e os acontecimentos “oficiais", são desarrumados, rearranjados, dotados de outra significação, e muitas vezes rebaixados. Este, o caso explícito do romance "As Naus" de Lobo Antunes, mas também, em muitos aspectos, do romance "O Pintor de Retratos" de Assis Brasil. Em ambos os romances

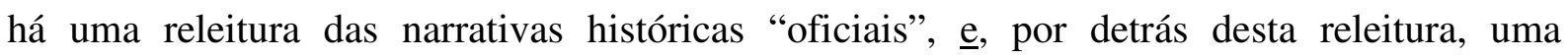
pergunta: o que nos caracteriza como civilização? Em que medida somos civilizados, em que medida somos bárbaros? Este ensaio busca uma resposta, ou ao menos, problematiza a questão posta em ambas as obras.

\section{O pintor de retratos: a trajetória do herói problemático}

Para Walter Benjamin (1985) há dois tipos exemplares de narradores: o camponês sedentário que repassa às novas gerações os conhecimentos tradicionais, e o marinheiro, que 
traz novas descobertas e novas narrativas fundadas numa visão de mundo alargada pelas viagens além mar. (BENJAMIN, 1985, p. 198-199).

Sandro Lanari insere-se aqui como o narrador-viajante, mas também como aquele que tenta, a todo custo, manter as tradições da família - daí sobrevêm as complexidades de seu caráter enquanto personagem. Se por um lado Sandro busca permanecer dentro de toda uma tradição de retratistas herdada por seu pai, por outro lado, vê-se imbricado na descoberta de uma nova estética e de uma nova forma de arte simbolizadas na fotografia de Nadar. Há no romance de Assis Brasil um embate entre a arte moderna nascente na Paris do século XIX, apresentada nos quadros dos impressionistas e nas fotografias de Nadar, e uma arte tradicional representada pelos retratistas que, ou esgotaram sua técnica (o livro de Cenino Cenini), ou apesar dela, não conseguem criar uma nova arte (como no caso do pintor La Grange) e caem numa existência ébria e sonolenta.

É justamente a falta de perspectivas que faz Lanari empreender sua viagem ao sul do Brasil. Neste sentido, o protagonista do romance, perfaz, em certa medida, a trajetória do herói tradicional tão bem fundamentada por Propp (1984). Sandro, depois de muitos infortúnios e peripécias, termina por estabelecer-se como fotógrafo em Porto Alegre. Sua existência anterior, nômade, indo de estância em estância, é transformada, e ele passa a morar num sobrado junto com sua esposa, e depois, seus filhos. Adquire com a fotografia, o status de pequeno burguês, passa a frequentar os mesmos ambientes da burguesia provinciana, e é, aparentemente, um herói romanesco que, superadas as faltas iniciais, empreende sua jornada rumo a um final feliz de completude e sucesso. Porém, o aburguesamento de Lanari, seu casamento e sua família, não são, neste caso, o verdadeiro sucesso da personagem.

Há no romance certas questões transcendentes que irão causar o desfecho final: o que é arte? O que é talento? O que faz de um homem, um artista verdadeiro? O que é civilização? O que é barbárie?

Ao retornar a Paris e procurar novamente por Nadar, Lanari se depara consigo mesmo: ele não passa de um tolo. Um tolo que se pretende artista. Sua miséria fica evidente quando, ao mostrar um instantâneo de um momento de barbárie para Nadar, ele ouve do fotógrafo que aquilo não é arte, mas sim, um ato tão bárbaro quanto à degola que ele presentifica em sua imagem. Desfeito da sua ilusão de artista, Lanari rasga em pedacinhos seu próprio retrato feito por Nadar. Num único gesto, ele simboliza a fragmentação do sujeito e sua desilusão para consigo mesmo. 
Incapaz da grande arte, reduzido a um fotógrafo medíocre, Lanari joga os pedaços de sua foto pela janela do trem. Ele já não é mais ninguém, ele é uma imagem fragmentada, esparsa, jogada na estrada, sem rumo certo, e que nem mesmo os meninos das redondezas conseguem juntar e compor numa única figura.

Sandro é a perplexidade de pensar-se um e descobrir-se nenhum, sem a arte, sem o talento, seja na pintura ou na fotografia. Sem o que o identifique como artista, Sandro torna-se ninguém. Durante toda a sua trajetória, Lanari busca uma espécie de utopia: tornar-se um grande artista. Ao final de sua trajetória ele é um fotógrafo famoso e rico, mas não é um grande artista, como descobre no estúdio de Nadar. Essa descoberta faz com que Lanari volte ao ponto de partida de sua vida, quando ele é ninguém. Nadar é o grande artista e nessa medida, é a antítese de Lanari. Por isso Sandro destrói a foto de Nadar e joga-a ao vento. Não é somente a si que ele desfaz, mas também é a imagem que o outro tem de si. E é justamente essa descoberta, essa volta ao princípio, que faz com que Sandro Lanari, escape ao protótipo do herói tradicional e torne-se, isso sim, um herói problemático, característico do romance contemporâneo. Ele é assim, solitário em sua busca frenética pela arte, em sua falta de perspectivas, sem conselhos para dar ou receber, sem uma identidade fixa ou definitiva. Lanari pode ser definido muito mais por sua complexidade e seus processos de mudança, no mais das vezes repentinos, seja por causa de uma ameaça de morte vinda do seu benfeitor, em nome da honra da filha, seja por causa de uma revolução.

Assim, no seu último gesto, Sandro personifica a distopia, a desilusão, o fim do sonho de ser um grande artista que ele buscou em terras estrangeiras. Essa trajetória iniciada numa utopia (a busca pela arte) e finalizada numa distopia (a descoberta de que não passa de um tolo) é o que caracteriza o herói problemático e sem saída do romance contemporâneo. Não sabemos o que sucederá a Lanari quando o romance chega a seu término, mas temos consciência de que tudo o que o protagonista construiu em sua vida não passou de uma grande ilusão sobre si mesmo. Assim como o protagonista, o leitor também cai em desalento. Não há nada a fazer, tudo já foi feito. Não há saída para a mediocridade, para a falta de talento. Descobre-se no ponto final do livro que não há salvação possível: não basta decorar o livro de Cenino Cenini ou aplicar todas as técnicas de Carducci. É necessário algo mais, uma grandeza de alma, um olhar, um dom, algo que escapa a toda técnica e toda ciência. É esse algo mais, chamado talento, que Lanari não possui. E o leitor, que segue seus passos na busca pelo retrato perfeito, pela foto do destino, descobre junto com ele, que de nada vale iludir-se, e que fama, reconhecimento, riqueza e sucesso, não são sinônimos de talento. 
Lanari termina as páginas do romance não como o herói coroado de êxito depois de muitas peripécias, mas como o herói rebaixado a tolo, depois de imaginar-se exitoso. Neste sentido, Assis Brasil reinventa e ressignifica a trajetória do herói tradicional e problematiza o que nas narrativas tradicionais seria o ponto de culminância, o sucesso do herói. Ao relativizar o significado do aburguesamento e do casamento de Sandro, o romancista retoma a narrativa tradicional para desconstruí-la: o herói bem-sucedido não é herói, é antes um medíocre. Essa inversão de valores, essa desconstrução da figura do herói, tornando-o subitamente um herói rebaixado, é que faz do protagonista de Assis Brasil um típico personagem do romance contemporâneo. Ele, ao final das contas, está só e mudo, sem mais nada para contar, sem mais razões para viver, apenas seguindo inerte, sentado no banco do trem, seguindo o fluxo do comboio. Comboio do destino, comboio da vida: essa vida contemporânea, sem nenhum sentido.

\section{As naus: história e ficção na antiepopeia lusitana}

Os Lusíadas, de Camões, são a epopeia por excelência: num mundo mítico, habitado por deuses gregos, sereias, bravos descobridores e navegantes, se instaura a imagem do Império Lusitano, um Império feito de marinheiros intrépidos, reis visionários, e terras a povoar, civilizar, descobrir. Goa, Macau, Timor, Angola, Moçambique, Cabo Verde, Brasil, são algumas das muitas terras que perfizeram o Império Lusitano. Se Camões, soldado do rei e poeta, cantou este império, e fundou nos seus versos, a pátria lusitana e o seu imaginário, Lobo Antunes, cinco séculos depois, recita um novo canto, desta vez em prosa, e desfaz o imaginário que Camões ajudou a fundar e que até hoje permanece vivo na memória e na visão de mundo dos portugueses.

Assim, em resposta à epopeia lusitana de Camões, Lobo Antunes criou a antiepopeia, o romance desconsolado dos retornados de África. Mas em que consiste a poesia de Camões e sua antítese? Em que termos podemos falar de poesia épica, epopeia e antiepopeia? Já que aqui falamos do mar português, citemos Benjamin:

\footnotetext{
No sentido da poesia épica, a existência é um mar. Não há nada mais épico do que o mar. Naturalmente, podemos relacionar-nos com o mar de diferentes formas. Podemos, por exemplo, deitar na praia, ouvir as ondas ou colher os moluscos arremessados na areia. É o que faz o poeta épico. Mas podemos também percorrer o mar. Com muitos objetivos, e sem objetivo nenhum. Podemos fazer uma travessia marítima e cruzar o oceano, sem terra à vista, vendo unicamente o céu e o mar. É o que faz o romancista. Ele é o mudo, o solitário. O homem épico limita-se a repousar. No poema épico, o povo repousa, depois do dia de trabalho: escuta, sonha e colhe. O romancista se separou do povo e do que ele faz. A matriz do romance é o indivíduo em sua solidão, o homem que não pode mais falar exemplarmente sobre suas preocupações, a quem ninguém pode dar conselhos, e que não sabe dar conselhos a
} 
ninguém. Escrever um romance significa descrever a existência humana, levando o incomensurável ao paroxismo. A distância que separa o romance da verdadeira epopéia pode ser avaliada se pensarmos na obra de Homero ou Dante. A tradição oral, patrimônio da epopéia, nada tem em comum com o que constitui a substância do romance. O que distingue o romance de todas as outras formas de prosa - contos de fadas, sagas, provérbios, farsas, - é que ele nem provém da tradição oral, nem a alimenta. (BENJAMIN, 1985, p. 54-55)

Porém, se no romance o herói é solitário e está longe de dar exemplos, ele tem outras características que o distinguem do herói épico. Geralmente habitando um tempo mítico, o herói épico traveste-se de ações e palavras que representam não só o coletivo como também a voz do autor do poema / epopeia. Neste sentido, o poema épico é univocal (possui uma única voz), ao passo que o romance tem por característica a polifonia (várias vozes) e o dialogismo (o diálogo entre as várias vozes / personagens). Além disso o romance situa-se num espaçotempo geralmente definidos, com características históricas e ideológicas que refletem a visão de mundo do romancista, bem como sua situação histórica, sócio-política-econômica. Esta perspectiva ideológica do romance, por certo o afasta do poema épico. Segundo Bakhtin há diversas diferenças entre o romance e a epopeia, dentre as quais, podemos citar as seguintes:

Geralmente o herói age no romance tanto quanto na narrativa épica. A diferença
deste do herói épico consiste em que ele não apenas age, mas também fala, e sua
ação não tem uma significação geral e indiscutível, ela não se realiza num mundo
épico incontestável e significante para todos. Por isso, esta ação sempre necessita de
uma ressalva ideológica, ela tem uma posição ideológica definida, que é a única
possível e que, por isso, é contestável. A posição ideológica do herói épico é
significativa para todo o mundo épico; ele não tem uma ideologia particular, ao lado
da qual possam existir outras. Naturalmente, o herói épico pode proferir longos
discursos (enquanto que o herói romanesco silencia), no entanto seu discurso não se
distingue no plano ideológico [...] e se confunde com o discurso do autor. Mas o
autor, também, não destaca sua ideologia: esta se funde à ideologia geral, a única
possível. A epopéia tem uma perspectiva única e exclusiva. O romance contém
muitas perspectivas, e o herói geralmente age em sua perspectiva particular. [...]. A
ação do herói no romance é sempre sublinhada por sua ideologia: ele vive e age em
seu próprio mundo ideológico [...] ele tem sua própria concepção do mundo
personificada em sua ação e em sua palavra. (BAKHTIN, 1990, p. 136-137)

Levando em conta o caráter ideológico das personagens, Lobo Antunes subverte a história oficial que parte do mito dos grandes navegadores, desconstrói uma a uma as personagens que fundaram o Império Lusitano, não só na vida real, mas também no imaginário do povo português, em especial, no seu maior épico: Os Lusíadas. Como um Camões ao revés, Lobo Antunes transforma os heróis da epopeia lusitana em homens comuns, retornados de África, que não têm lugar na sociedade portuguesa pós-25 de abril, que vivem perambulando pelas ruas de Lisboa sem conseguir um emprego ou uma casa decentes, que vivem na mais abjeta miséria e solidão, e tudo o que possuem são memórias, são trastes e papéis velhos, coroas de lata, garrafas de gim, ou ainda o cadáver do pai insepulto. 
Assim, Pedro Álvares Cabral, navegador responsável pela descoberta do Brasil, é descrito como um retornado de Angola, sem parentes no "reyno", e que traz consigo sua mulher, uma mulata, e o filho. Pedro Álvares Cabral é enviado para uma pensão miserável, a Residencial Apóstolo das Índias, onde sua mulher é prostituída a título de pagamento pelo alojamento e alimentação. Sua peregrinação por Lisboa em busca de emprego é infrutífera, e, ao cabo do dia, encontra-se novamente na pensão, bebendo junto a Diogo Cão (outro grande navegador português, responsável por descobrir muitas terras e rotas em África), aqui descrito como um velho bêbado que vive de reminiscências das descobertas e tenta, em vão, ao sopé da porta, tocando um palito no chão, descobrir novas possibilidades de outras terras. Podemos ver assim, a história portuguesa das navegações contada sob outro prisma, o prisma da distopia, da miséria, do vício, da ruína. Tudo o que sobra aos navegadores portugueses, ao cabo de quinhentos anos, são reminiscências e a exclusão completa de suas figuras na sociedade portuguesa atual. Eles já não fazem mais sentido na história contemporânea, são como espectros que ficam vagando sem ter um lugar que lhes caiba. Não possuem nada, exceto sua própria solidão. São retornados de uma África que não deu certo como projeto colonial e que se findou numa guerra sangrenta e sem vencedores. Ao mesmo tempo, são figuras de um Portugal que não já existem: o Portugal das Descobertas e das grandes navegações, o Portugal do Império Ultramarino.

Mesmo o próprio Camões é apresentado nesta antiepopeia como um "homem de nome Luís a quem faltava a vista esquerda" (p.14), e que fica aguardando no Cais de Alcântara por seus pertences (que jamais chegam) sentado em cima do caixão do pai. Podemos tomar essa imagem de Camões como a imagem do poeta que, na tentativa de escrever um épico, acaba mesmo é tentando reviver uma pátria morta. O pai morto e insepulto de Camões, acaba por fim servindo de adubo às plantas aparentemente medicinais, mas que na realidade são carnívoras, cultivadas por Garcia da Orta em seu apartamento. Ora, podemos pensar nestas plantas que inclusive comem os filhos e mesmo o pai de Garcia da Orta, como uma espécie de símbolo do fascismo salazarista, que em nome de um império moribundo e alimentando-se do imaginário deste império (o cadáver do pai de Camões) levou seus filhos, em tenra idade, a morrerem em guerras coloniais nas terras de África, devorados ou por balas e lanças dos guerrilheiros ou por doenças tropicais.

Desta maneira, Lobo Antunes conta a história de Portugal, não a partir da utopia do Império, mas a partir da distopia da Revolução de Abril. Ficcionalizando as grandes figuras heróicas do imaginário português, ora como retornados e excluídos, ora como lunáticos, 
bêbados, ou proxenetas, que mesmo depois de perderem tudo, ainda se erguem na vida do submundo de Lisboa, o autor nos mostra a outra face da história portuguesa, fazendo uma releitura das descobertas que acabaram numa sociedade de marginalizados, excluídos, desempregados e prostitutas. O projeto civilizacional português afunda-se, assim, não só em África, como em terras lusitanas. No romance de Lobo Antunes, a própria Revolução dos Cravos e a tentativa de um governo socialista é ridicularizada. Há pelo menos duas passagens em que isto fica evidente, uma durante a chegada dos retornados a Lisboa e que segue:

[...] e então uma voz divina, imensa, autoritária, nascida não só das madeixas complicadas do tenente mas de todos os pontos da sala, [...] uma voz de garagem ou de despenhadeiro [...] informou com ferocidade, damas e cavalheiros, informou com pompa, senhoras e senhores, que se encontravam no Hotel Ritz por pura benevolência paternal das autoridades revolucionárias preocupadas em zelar pelo conforto e tranqüilidade dos seus filhos até o Estado democrático, nascido, com a ajuda da parteira mão castrense, do ventre putrefacto do totalitarismo fascista que durante decênios nos garroteou e oprimiu, conseguir casas ou prefabricados ou apartamentos nos bairros econômicos para as vítimas da ditadura felizmente extinta, e que em nome, camaradas, da luta de classes e da construção do socialismo dirigida pela vanguarda política do exército, passariam a ser punidos com a forca, a decepação da mão esquerda, a extracção de vísceras pelas costas ou o degredo em Macau, os intoleráveis abusos de assar sardinhas nos lavatórios, engasgar os ralos com tornozelos de faisão, cozinhar refogados e fritos nas cerâmicas dos chuveiros, vender as torneiras, concebidas por arquitectos franceses, nos antiquários caquéticos da Rua de São Bento, assim como servir-se das cortinas estampadas do hotel para blusas e adornos, tenho dito, de barregã de moiro (ANTUNES, 2011, p. 43-44).

A outra passagem, refere-se a Manoel de Sousa de Sepúlveda, no romance também um retornado de África e que ao chegar em seu apartamento na Costa da Caparica, dá-se conta de que este foi tomado de assalto pelo regime socialista e agora é uma espécie de "centro de recuperação para doenças da espinha". Ao dizer que o apartamento lhe pertencia e que poderia trazer a escritura para prová-lo, Sepúlveda ouve:

— Traz a escritura, caralho? Traz a escritura? Eu quero lá saber da escritura, a escritura que se foda: estamos em democracia, seu camelo, os prédios pertencem a quem mora neles, a época da Pide acabou.

— O gajo diz que chegou de África, não sabe o que é o socialismo [...]

- Olha-me um que não sabe o que é o socialismo, o analfabeto, magoou-se o das farripas num pesar sincero [...]. Chegou agora de África, coitado, não vinha cá há séculos, explorava os camaradas pretinhos, julga que a casa é dele. Isto pertence ao povo, amigo, pertence à gloriosa vanguarda do proletariado, foi ocupado revolucionarmente, percebe? Se for à Câmara encontra lá o meu nome como dono e gerente deste centro de recuperação para doenças da espinha, e ainda o urso tem a lata de me falar em escrituras (ANTUNES, 2011, p. 61-62).

Desta maneira, Lobo Antunes desconstrói tanto o passado, transformando os heróis da epopeia em heróis rebaixados, em homens comuns sem eira nem beira, quanto o presente, 
tratando a Revolução de Abril como mais um equívoco na história portuguesa, como mais um passo rumo à miséria e à demagogia governamental. No romance de Lobo Antunes Portugal não tem saída: entre um passado que insiste em bater à porta, mesmo moribundo, e um presente socialista que nada resolve, o país vê-se frente o desemprego e miséria. Carregando cadáveres, alimentando plantas carnívoras, ou ainda caindo numa espécie de loucura coletiva, já que o final do livro resume-se a um grupo de doentes tísicos, à espera do retorno de Dom Sebastião na praia da Ericeira, os portugueses perdem-se em meio à neblina. Não há futuro em Portugal. "Tudo é incerto e derradeiro. Tudo é disperso, nada é inteiro. Ó Portugal, hoje és nevoeiro [...]" (PESSOA, 1959, p. 104).

\section{Entre o pampa e o mar: questões de civilização e barbárie}

Segundo o ensaio de Francis Wolff (2004), existem três sentidos para a barbárie, e concomitantemente, para a civilização. Assim, poderíamos dividir civilização e barbárie das seguintes formas: 1. Numa primeira acepção do termo, civilização designa um processo, supostamente
progressivo, pelo qual os povos são libertados dos costumes grosseiros e
rudimentares das sociedades tradicionais e fechadas para se "civilizar", o que supõe
que pertençam a uma sociedade maior, aberta e complexa e, portanto, urbanizada. A
civilização designa esse processo de paulatino abrandamento dos costumes, de
respeito aos modos, ao refinamento, à delicadeza, à elegância, ao pudor, etc.
notadamente no cumprimento das funções naturais e das relações sociais. [...] O
bárbaro, no imaginário popular, é o canibal que vive quase nu no meio das selvas. É
também o camponês não educado, em oposição à civilidade da cidade. [...] O
bárbaro supostamente se inclui num estágio inferior da evolução política, num
estágio pré-civil ou, pelo menos, pré-urbano.

2. Na segunda acepção entre barbárie e civilização, temos referida a questão da arte e da cultura como uma forma de cultivar a espiritualidade humana. Teríamos assim, a civilização expressa através da música, da literatura, da pintura, etc.. Em contraposição à evolução artística, teríamos o bárbaro que destrói estátuas, pilha igrejas, ou seja, pertence a um estágio anterior da cultura humana.

3. Na terceira acepção do termo, temos então a barbárie e a civilização em oposição no que torna os homens, de fato, "humanos": o respeito pelo outro, a cooperação, assistência, compaixão, conciliação e pacificação das relações - em oposição ao que se supõe natural ou bestial, a uma violência vista como primitiva ou arcaica, a uma luta impiedosa pela vida. [...] A barbárie representa aqui a perda de qualquer sentimento humanitário (assistência ao mais fraco, piedade, benevolência) e parece, nesse caso, resultar da dessocialização e da desculturação. [...] De modo geral, a barbárie, considerada nesse sentido, designa fenômenos essencialmente destruidores, manifestações de desumanidade incontrolada; fala-se em "crime bárbaro" em referência a mutilações atrozes, assassinatos horríveis, sacrifícios humanos em massa, holocaustos, etnocídios, genocídios (WOLFF, 2004, p. 21-23).

A partir destas três acepções de civilização e barbárie, podemos identificar o homem sul-riograndense, retratado no romance de Assis Brasil como um bárbaro nos três sentidos: ele é um homem do campo, que pouco ou nada sabe da vida na Polis, da política de Estado, das 
relações interpessoais. O gaúcho é antes um homem que vive em constante contato com a natureza, e pouco ou nada tem de cultura. Ele não possui letramento, tampouco vê a cultura ou a arte como um bem da civilização. Já Érico Veríssimo, mostrava em seu magistral romance "O Tempo e o Vento", o quanto a cultura e a arte eram alienígenas e não pertencentes ao universo do gaúcho. Assim, a música, a literatura, a pintura, eram vistas como "coisa de fresco", de homens que não possuem valentia ou hombridade suficientes para lidar com guerras, revoluções, e a vida rude do campo. Desta maneira, a arte é vista como um elemento quase descartável, e o artista, como um diletante, um inútil na sociedade. No caso do romance de Assis Brasil, somente os estancieiros são capazes de reconhecer a arte de Lanari. Ainda assim, no auge da revolução, Sandro é jogado para a posição de fotógrafo justamente pelo fato de o fotógrafo anterior ter sido morto em batalha. A fotografia não é vista como uma arte é vista como um troféu de guerra. E a própria maneira de vencer a guerra é uma forma exacerbada de barbárie, visto o que é feito dos prisioneiros. Essa terceira forma de barbárie fica bem explicitada nas seguintes passagens do livro de Assis Brasil:

\begin{abstract}
As partes digladiavam-se nos campos sem fim. As pelejas eram travadas com fuzis, baionetas, lanças e facões, sob o comando de proprietários rurais improvisados em coronéis. Eles levavam seus servos para a luta, formando esquadrões de cavalaria. [...]. Como resultava caro manter os prisioneiros, matavam-nos. Esses infelizes eram organizados numa fila, e um homem cruel, chamado degolador, rasgava-lhe as carótidas com uma faca. $\mathrm{O}$ agonizante, entregue a si mesmo, levava as mãos à garganta, tentando estancar o fluxo de sangue. Dava alguns passos trôpegos, as pernas cediam e ele tombava (p. 120).

À frente de um grupo de soldados erigia-se o vulto sombrio de Adão Latorre. Era uma pausa na carnificina. Latorre tinha o torso nu, lavado em sangue. Os cabelos empastavam-se de suor. Limpou a testa com as costas da mão que empunhava a faca. Era uma faca pequena, infantil. Entregaram-lhe um jovem de rosto digno, barba cerrada. Na Europa, poderia ser um príncipe. Em meio a insultos, obrigaramno a ajoelhar-se. Latorre veio por detrás. Em sua mão, a faca luziu. Com ela bateu de leve no nariz do prisioneiro. Surpreendido, ele alçou a cabeça. Num movimento rápido, Latorre cortou-lhe as carótidas. O homem tombou para a frente, rendendo-se à morte como se a esperasse desde o nascimento. Os esguichos de sangue pulsavam, ampliando a enorme mancha escura no chão. Os soldados riam. Um deles chutou o flanco do moribundo. Latorre limpou a testa mais uma vez. Ao fazer isto, ergueu o rosto. Corria uma penumbra de maldade naquela mirada. (BRASIL, 2001, p. 134).
\end{abstract}

Podemos vislumbrar na passagem acima, toda a barbárie que envolveu as revoluções no Rio Grande do Sul, em especial a Revolução Federalista, tratada no romance, que ficou também conhecida como a "revolução da degola". A foto do Destino é subtraída pela câmara de Lanari num dos momentos mais cruéis de degola onde Adão Latorre está prestes a matar um homem. Não é uma foto artística, é uma foto da barbárie e que em certa medida, se coaduna com o ato bárbaro, referendando-o, imortalizando-o na imagem sem, no entanto, impedi-lo. Em contrapartida, o próprio Sandro desumaniza-se e não compreende as palavras de Nadar: 
A arte, meu caro Senhor Lanari, é a única filosofia que pode explicar a natureza humana. [...] A arte não existe sem a humanidade do homem que a cria, e a humanidade de quem a vê. [...] A questão é apanhar o caráter moral do modelo: isso é arte. Ouça: eu jamais conseguiria essa foto se, antes de ser fotógrafo, eu não fosse ser humano. [...] Isso não é arte. Isso é um ato de barbárie. Antes tivesse socorrido esse infeliz ao invés de tirar fotografias. Fotografar condenados à beira da morte é um ato imbecil e torpe. Para captar a alma de alguém, é preciso que seja o homem por inteiro. Aí teremos arte. E só possuindo uma alma se é artista (BRASIL, 2001, p. 175 e 178).

Temos desta maneira a oposição entre Nadar (civilização) e Lanari (barbárie) se entendermos que a civilização pressupõe o respeito ao outro, a compaixão, a assistência ao mais fraco. A arte sem a compaixão torna-se propaganda de Estado, como o foi no caso dos Nazistas. A arte só é índice de civilização quando ela remete à própria condição humana e a eleva. Uma arte que degrada o humano pode ser considerada cultura, mas podemos considerála como civilização? Esta autora julga que não. Assim, mesmo o que Lanari considerava artístico, é apenas uma ilusão, uma forma degradante de arte, como disse Nadar, um ato torpe, imbecil.

Porém, se no Brasil, e no caso específico no pampa sul-rio-grandense temos três formas de barbárie e pouca ou nenhuma civilização, (como constata o romance de Assis Brasil), pelo menos nos idos do século XIX e início do século XX, em contrapartida, em Portugal, temos uma barbárie camuflada. Se levarmos em consideração que a compaixão, a cooperação, o respeito pelo outro, a assistência aos mais fracos é um índice de civilização, então teremos uma sociedade impiedosa e semibárbara sendo narrada nas páginas do romance de Lobo Antunes. Desta forma, podemos vislumbrar Pedro Álvares Cabral sendo interpelado ao chegar à pensão Residencial Apóstolo das Índias e ao dar resposta negativa, temos a subtração de sua esposa ao cabedal de prostitutas comandadas pelo dono da espelunca, como segue nos seguintes trechos:

\footnotetext{
- Não tens as coroas, mocinho? [...]. A tua esposa vai trabalhar lá em baixo num bar até a contazinha da pensão ficar paga [...] e dei com a mulata vestida de fantoche ou de palhaço de circo [...] com a carapinha apanhada num carrapito de laços, unhas prateadas, baton, pálpebras verdes e uma vírgula de espanto na testa franzida. A velha, de agulha na mão, compunha-lhe às pressas as pregas de lamé das ancas (ANTUNES, 2011, p. 27-28)
}

E se Francisco Xavier prostitui a mulher alheia, ele também prostitui sua própria esposa a quem troca por uma passagem para Lisboa. Mesmo arrependendo-se mais tarde, podemos ver nesse tipo de "negócio" não só um índice de barbárie como também de decadência da civilização ocidental, aqui representada pelos portugueses. Lembremos que o próprio personagem histórico é aqui subvertido e transformado num proxeneta e dono de 
pensão. Assim, temos nas palavras de Lobo Antunes, uma forma de exploração e degradação do humano, de falta de compaixão e respeito ao próximo, um excesso de egoísmo, e uma visão mercantilista das relações:

Nem cinemas, nem piscina: apenas um barraco em pedaços entre os pedaços de
barraco que cercavam a antiga cidade colonial dos mercadores de negros, e a minha
mulher, trinta e um anos e sete meses mais nova do que eu, trocada ao meu
compadre por um bilhete de avião para Lixboa [...] Ainda não é maior nem tem
doenças, eu, demorei um tempo dos diabos a ensiná-la a obedecer, faz tudo o que
lhe ordenares, passa a roupa a ferro, conhece receitas indianas, ajuda-te a vender os
manipansos, aonde é que aos oitenta encontras gaja assim? (ANTUNES, 2011, p.
30-31)

Essa mesma visão mercantilista e a falta de compaixão e respeito são visíveis no abuso de autoridade do cabo em relação ao caixão onde está o cadáver do pai de Camões. Sem acreditar que ali haja um corpo e não contrabando, o caixão é violado:

- Um cadáver? Desconfiou o cabo. Um cadáver ou tabaco americano, nosso amigo? Gitanes, Marlboro, anis, perfumes franceses, vermutes, uma dúzia de radiozinhos de pilhas japoneses. Você quer convencer-me que traz um cadáver aí? [...] Os guardas, de cócoras, aliviaram os parafusos, esboroaram a placa de estearina que cintava a urna, desfizeram a canivete as rendas do forro, um vento de amoníaco ascendeu do caixão [...] (ANTUNES, 2011, p. 21-22).

Temos desta maneira, explicitada a barbárie do Estado, o abuso de autoridade, a falta de assistência aos mais fracos. Se a sociedade rio-grandense é bárbara por seus métodos de guerra, por sua falta de cultura, pelos usos grosseiros e rurais, a sociedade portuguesa é bárbara na falta de compaixão e respeito pelo próximo, no abuso do poder das autoridades, na visão mercantilista das relações, no uso do corpo feminino como mercadoria de troca e como forma de escravidão. Assim, a barbárie institui-se em ambas as sociedades, em ambos os universos ficcionais e mostra-nos o revés da história oficial. Podemos enxergar ambos os romances como antiepopeias, recontando a história de seus respectivos países sob o prisma do herói rebaixado, solitário, sem eira nem beira, sem salvação. Assis Brasil põe em evidência pelo olhar do outro, do estrangeiro, a barbárie em que vive mergulhada a sociedade riograndense, e ao mesmo tempo, evidencia a própria desumanização do outro, quando se insere nesta sociedade. Lobo Antunes reescreve de forma iconoclasta a antiepopeia dos navegadores e figuras míticas de Portugal, rebaixando-os à condição de heróis problemáticos e solitários, sem ter um rumo certo, sem um destino a encontrar, sem casa, sem dinheiro, sem emprego, sem mulher. Não há consolo nem amor possível numa sociedade impiedosa onde seres humanos são tratados como meras mercadorias ou simplesmente são descartados, jogados numa pensão, num hospício, num hospital, ou mesmo numa casa abandonada. Não há espaço 
para os heróis do passado, assim como não há espaço para os retornados de África. Entre o pampa e o mar, tenta-se sobreviver numa sociedade que busca ser civilizada, mas não o é completamente. Há nas distâncias, a problematização do que o Ocidente costumou chamar de Civilização. Segundo Wolff,

\begin{abstract}
civilização não é cultura, mas é a cultura apenas no que esta supostamente tem de mais elevado, ou é a cultura supostamente mais elevada - qualquer que seja o aspecto que se queira valorizar: a socialização, o saber, as relações humanas em geral. Bárbaro, portanto, é o indivíduo, a etnia, a sociedade, a cultura que parece estranha aos valores ao mesmo tempo mais elevados e mais evoluídos da humanidade. Em suma, a oposição entre civilização e barbárie é a oposição entre o Bem e o Mal (WOLFF, 2004, p. 25).
\end{abstract}

Assim, cabe-nos perguntar em que medida somos nós civilizados? Em que medida somos bárbaros? A resposta está dada em ambos os romances, mas esta autora se furtará a respondê-la neste ensaio. Quem ler, saberá. "Vê longe a vida. Nunca a interrogues. Ela nada pode dizer-te. A resposta está além dos deuses.” (PESSOA, 1996, p.107).

\title{
Referências
}

ANTUNES, António Lobo. As Naus. Rio de Janeiro: Objetiva, 2011.

BAKHTIN, Mikhail. Questões de Literatura e de Estética (A Teoria do Romance). São Paulo: Hucitec, 1990.

BENJAMIN, Walter. Magia e técnica, arte e política - ensaios sobre literatura e história da cultura. São Paulo: Brasiliense, 1985.

BRASIL, Luís Antônio de Assis. O Pintor de Retratos. Porto Alegre: L\&PM, 2001.

HUSTON, Nancy. A Espécie Fabuladora - um breve estudo sobre a humanidade. Porto Alegre, L\&PM, 2010.

PESSOA, Fernando. Mensagem. Lisboa: Edições Ática, 1959.

Poesias. Porto Alegre: L\&PM, 1996.

PROPP, Vladimir. Morfologia do Conto Maravilhoso. São Paulo: Forense Universitária, 1984.

RODRIGUES, Inara de Oliveira. Entre a história e a ficção: diálogo de várias vozes no resgate da utopia. Tese de Doutorado - PUCRS. Porto Alegre, 2000.

WOLFF, Francis apud NOVAES, Adauto (org.). Quem é Bárbaro? In: Civilização e Barbárie. São Paulo: Companhia das Letras, 2004.

[Recebido em fevereiro de 2013 e aceito para publicação em outubro de 2013] 


\section{Between grassland and the sea: questions of civilization and barbarity}

Abstract: This paper aims to clarify issues about the contemporary historic novel as the notion of problematic hero, the review of ideologies and miths, the problematization of History in ficcion and above of all the issue that guides this essay: the notion of civilization and barbarity wich is inside the construction of Western identity. To do so, were used the theoric approaches of Bakhtin (1990), Benjamin (1985), Wolff apud Novaes (2004) and Rodrigues (2000). In this sense, the author searched to show the aspects written above in the following novels: "The Portrait's Paintor" by Assis Brasil (2001), and "The Ships" by Lobo Antunes (2011).

Keywords: Contemporary Historic Novel. Ficction. Civilization. Barbarity. Problematic Hero.

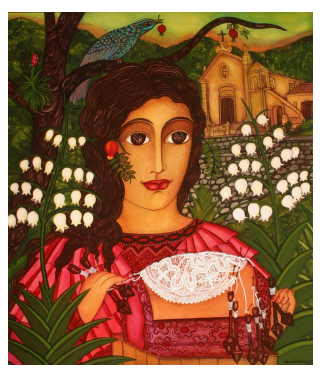

